\title{
Direct monitoring of bicarbonate transport by emission spectroscopy
}

Luis Martínez-Crespo, ${ }^{a}$ Sarah H. Hewitt, ${ }^{b}$ Nicola Alessandro De Simone, ${ }^{C}$ Vladimír Šindelár ${ }^{c}{ }^{c}$ Anthony P. Davis, ${ }^{d}$ Stephen Butler, ${ }^{* b}$ and Hennie Valkenier*a

\footnotetext{
a. Université Libre de Bruxelles (ULB), Engineering of Molecular NanoSystems, Ecole polytechnique de Bruxelles, Avenue F.D. Roosevelt 50, CP165/64, B-1050 Brussels, Belgium. Hennie.Valkenier@ulb.ac.be

b. Loughborough University, Department of Chemistry, Epinal Way, Loughborough, LE11 3TU, United Kingdom. S.J.Butler@lboro.ac.uk

c. Masaryk University, Department of Chemistry and RECETOX, Faculty of Science, Kamenice 5, 62500 Brno, Czech Republic.

d. University of Bristol, School of Chemistry, Cantock's Close, Bristol, BS8 1TS, United Kingdom.
}

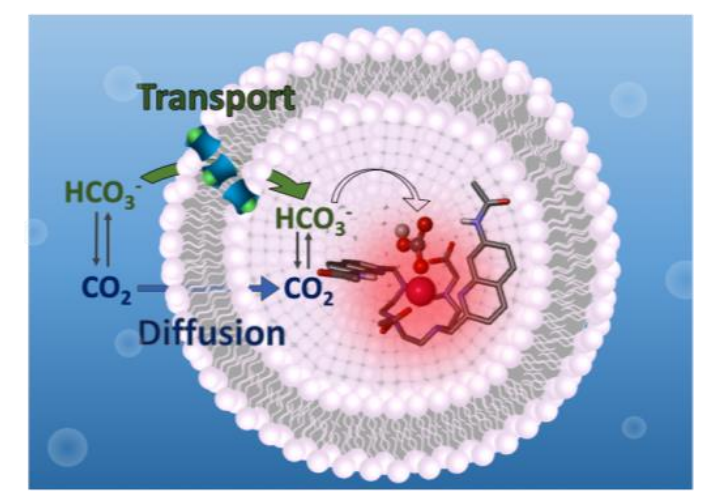

\section{Abstract}

The transmembrane transport of bicarbonate is a key step in many important biological processes, while problems with bicarbonate transport are at the origin of various diseases. Over the past 10 years, many anionophores that have been developed for the transport of chloride, have also been tested as bicarbonate transporters. However, methodology to directly monitor the kinetics of transport of bicarbonate is lacking, hence indirect methods have been used, which mainly rely on the monitoring of chloride concentrations.

Here we present an assay that allows the kinetics of bicarbonate transport into liposomes to be monitored directly, using emission spectroscopy. The assay utilises an encapsulated europium(III) complex, which exhibits a large increase in emission upon binding of bicarbonate. The advantages of this assay over existing methodology are that concentrations of bicarbonate are monitored directly and with a high sensitivity. This allows studies at very low concentrations of anionophores, and for the mechanisms of bicarbonate transport to be unravelled. We have distinguished classical antiport with bicarbonate from mechanisms involving $\mathrm{CO}_{2}$ diffusion and the dissipation of a $\mathrm{pH}$ gradient. Furthermore, the use of a standard fluorescence spectrometer and liposomes with a diameter $200 \mathrm{~nm}$ makes this assay readily and reliably applicable in many laboratories, where it can facilitate the development of bicarbonate transporters for applications in physiological studies or therapies. 
Transport of $\mathrm{HCO}_{3}{ }^{-}$across lipid bilayer membranes of living organisms is crucial for various processes, such as the regulation of $\mathrm{pH}^{1}$ and the removal of metabolic waste. ${ }^{2} \mathrm{~A}$ first example is found in red blood cells, which take up carbon dioxide that is excreted from cells in tissues as a waste product of aerobic respiration, and convert it into $\mathrm{HCO}_{3}{ }^{-}$. The bicarbonate transporter $\mathrm{AE} 1$ is an anion exchanging membrane protein that transports $\mathrm{HCO}_{3}{ }^{-}$out of the red blood cells, in exchange for $\mathrm{Cl}^{-}$. This process prevents acidification of tissues and allows $\mathrm{HCO}_{3}{ }^{-}$to travel to the lungs in the blood stream. In the lungs the reverse processes will take place: $\mathrm{HCO}_{3}{ }^{-}$is transported into red blood cells (and $\mathrm{Cl}^{-}$out) by AE1, after which the carbon dioxide diffuses from the red blood cells, to finally get exhaled. ${ }^{2}$ Furthermore, $\mathrm{HCO}_{3}{ }^{-} / \mathrm{Cl}^{-}$exchange by proteins from the SLC26 family and $\mathrm{Cl}^{-}$and $\mathrm{HCO}_{3}{ }^{-}$transport by the channel CFTR play important roles in secretion of $\mathrm{HCO}_{3}{ }^{-}$and liquid into the lungs. ${ }^{2,3} \mathrm{~A}$ second example is found in kidneys, where reabsorption of $\mathrm{HCO}_{3}{ }^{-}$takes place to avoid acidification of the organism. The $\mathrm{HCO}_{3}{ }^{-} / \mathrm{Cl}^{-}$ exchanger $\mathrm{AE} 1$ is present in certain parts of the tissue, while in other parts the protein NBCe1 performs symport of $\mathrm{HCO}_{3}{ }^{-}$and $\mathrm{Na}^{+}$. The gastrointestinal tract provides a third example, as $\mathrm{HCO}_{3}{ }^{-}$is secreted to neutralise stomach acid. Furthermore, in the intestines the $\mathrm{HCO}_{3}{ }^{-} / \mathrm{Cl}^{-}$exchange by proteins of the SLC26 family is coupled to $\mathrm{H}^{+} / \mathrm{Na}^{+}$exchange by transport protein NHE3. This leads to the net reabsorption of $\mathrm{NaCl}$, which in turn drives the reabsorption of water. These are only some examples of important biological processes that involve transmembrane transport of $\mathrm{HCO}_{3}{ }^{-}{ }^{2}$

The importance of $\mathrm{HCO}_{3}{ }^{-}$transport is also demonstrated by diseases that are linked to mutations in $\mathrm{HCO}_{3}{ }^{-}$transporting proteins. Examples are haemolytic anaemia, renal diseases, congenital chloride diarrhoea, and glaucoma. ${ }^{2}$ Altered expression patterns of $\mathrm{HCO}_{3}{ }^{-}$transporters have been observed in many types of cancer as well. ${ }^{4}$ Many symptoms of the congenital disease cystic fibrosis (CF), primarily associated with deficient $\mathrm{Cl}^{-}$transport, find their origin in a lack of $\mathrm{HCO}_{3}{ }^{-}$crossing epithelial cell membranes. ${ }^{5,6,7}$

Supramolecular chemists have envisaged to perform the transport of $\mathrm{HCO}_{3}{ }^{-}$using synthetic anion receptors. ${ }^{8,9}$ While the development of $\mathrm{HCO}_{3}{ }^{-}$transporters was defined as "an interesting target with potential utility" by A. P. Davis, Sheppard, and Smith in $2006,{ }^{10}$ J. T. Davis, Gale, Quesada and co-workers reported in 2009 that a series of isophthalamides and the natural compound prodigiosin can act as $\mathrm{Cl}^{-} / \mathrm{HCO}_{3}{ }^{-}$exchangers. ${ }^{11}$ Since then, many different anion transporters have been shown to transport $\mathrm{HCO}_{3}{ }^{-}$, of which the vast majority have urea, ${ }^{12,13,14}$ thiourea, ${ }^{15,16,17}$ squaramide, ${ }^{18,19}$ amide, ${ }^{11,20,21}$ or pyrrolic $\mathrm{N}-\mathrm{H}$ groups ${ }^{22,23}$ as $\mathrm{H}$-bond donors. Phenyl rings with electron withdrawing substituents are often connected to these functional groups to increase the acidity of the $\mathrm{N}-\mathrm{H}$ groups and improve both the affinity for anions and the rates of transport. ${ }^{12-14,17-19} A$ series of compounds that was shown to function efficiently as $\mathrm{Cl}^{-} / \mathrm{HCO}_{3}{ }^{-}$exchanging anionophores, but without employing $\mathrm{N}-\mathrm{H}$ based $\mathrm{H}$-bond donors, are the fluorinated bambus[6] urils. ${ }^{24}$ These macrocyclic receptors have an electron deficient cavity formed by twelve (polarised) methine $\mathrm{C}-\mathrm{H}$ groups, which leads to exceptionally high affinity constants in the range of $10^{7}-10^{11} \mathrm{M}^{-1}$ in acetonitrile for $\mathrm{HCO}_{3}{ }^{-}, \mathrm{Cl}^{-}$, and $\mathrm{NO}_{3}{ }^{-}$, despite the absence of acidic protons. Other anionophores employing $\mathrm{C}-\mathrm{H}$ groups for anion recognition were, however, unable to transport $\mathrm{HCO}_{3}{ }^{-25,26}$

In the context of $\mathrm{CF}$, the strategy of employing relatively small synthetic molecules to achieve anion transport in epithelial cell membranes gave encouraging results for chloride transport by various compounds. ${ }^{27,28,29,30,31,32}$ More recent results suggest that small synthetic anion carriers can transport $\mathrm{HCO}_{3}{ }^{-}$in cells as well. ${ }^{33}$ The properties of airway surface liquid (ASL), which are linked to transport of $\mathrm{HCO}_{3}{ }^{-},{ }^{34}$ were restored significantly in $\mathrm{CF}$ airway epithelial tissue, ${ }^{35}$ while the channel forming natural product amphotericin B, additionally, showed improvements in the ASL of CF pigs in vivo. ${ }^{36}$ 
To further develop $\mathrm{HCO}_{3}{ }^{-}$transporters for biological or therapeutic applications, direct and sensitive methods to study the transport of this anion would be of great benefit. So far, the ability of anionophores to transport $\mathrm{HCO}_{3}{ }^{-}$has mainly been studied by indirect methods. In most cases, a chloride selective electrode has been employed to study the efflux of $\mathrm{Cl}^{-}$from liposomes that were dispersed in a medium containing $\mathrm{HCO}_{3}{ }^{-} \cdot{ }^{37,11,13-19,21-23,33}$ The transport of $\mathrm{Cl}^{-}$out of the liposomes proceeds only if another anion is transported in the opposite direction, to balance the charge by an antiport process. From the observed efflux of $\mathrm{Cl}^{-}$it is then concluded that an influx of $\mathrm{HCO}_{3}{ }^{-}$has occurred. Alternatively, a halide-sensitive fluorescent probe, such as lucigenin or SPQ, is encapsulated in liposomes and the influx (or efflux) of $\mathrm{Cl}^{-}$ is monitored via the quenching of the fluorescence. ${ }^{12,20,24,25,38}$ This is again an indirect method to study the transport of $\mathrm{HCO}_{3}{ }^{-}$, which is assumed to balance the charge from the influx of $\mathrm{Cl}^{-}$if transport is observed. A third indirect method to monitor transport of $\mathrm{HCO}_{3}{ }^{-}$is by the recently reported osmotic assay, where the efflux of $\mathrm{HCO}_{3}{ }^{-}$by an anionophore is accompanied by the efflux of a cation (by a cationophore), resulting in an osmotic efflux of water, that can be observed as a change in the scattering intensity of the liposome dispersion. ${ }^{17}$ To the best of our knowledge, the only reported alternative for these indirect methods to study the transmembrane transport of $\mathrm{HCO}_{3}{ }^{-}$is the use of ${ }^{13} \mathrm{C} \mathrm{NMR}$ spectroscopy, which can be employed in combination with $\mathrm{NaH}^{13} \mathrm{CO}_{3} \cdot{ }^{11,15,16,36,38}$ A paramagnetic species can be added after the influx (or efflux) of the isotopically labelled bicarbonate to distinguish interior from exterior bicarbonate. The disadvantage of this method is that it is difficult to monitor the transport process over time with standard instrument configurations. ${ }^{36}$ Furthermore, the osmotic and ${ }^{13} \mathrm{C}$ NMR assays have a relatively low sensitivity and require large concentrations of transporter in the liposomes.

An emission-based assay that allows direct monitoring of $\mathrm{HCO}_{3}{ }^{-}$transport would surmount these difficulties. Rates of $\mathrm{HCO}_{3}{ }^{-}$transport could be quantified, and results obtained by indirect methods could be verified. It would also offer more possibilities to study the mechanism of transport and exchange processes with different anions. Such an assay requires a probe whose emission properties change in the presence of $\mathrm{HCO}_{3}{ }^{-}$. The europium complex [Eu.L $\left.{ }^{1}\right]^{+}$developed by Butler (Fig. 1C) showed an increase in the intensity of several Eu(III) emission bands upon binding of $\mathrm{HCO}_{3}{ }^{-}$but negligible responses to $\mathrm{Cl}^{-}$ and $\mathrm{NO}_{3}{ }^{-}$and this made it an ideal candidate for the development of the transport assay. ${ }^{39}$ We present here the use of this probe encapsulated in liposomes, to directly monitor the transport of bicarbonate across the lipid bilayers by fluorescence spectroscopy. We have used this new assay to study the $\mathrm{HCO}_{3}{ }^{-}$ transport by different highly potent synthetic anionophores (Scheme 1), ${ }^{12,24,40}$ for which transport was previous observed indirectly in the lucigenin assay (Fig. S1). Furthermore, this novel $\mathrm{HCO}_{3}{ }^{-}$assay allowed the study of the kinetics and mechanisms of $\mathrm{HCO}_{3}{ }^{-}$transport by these ionophores. 

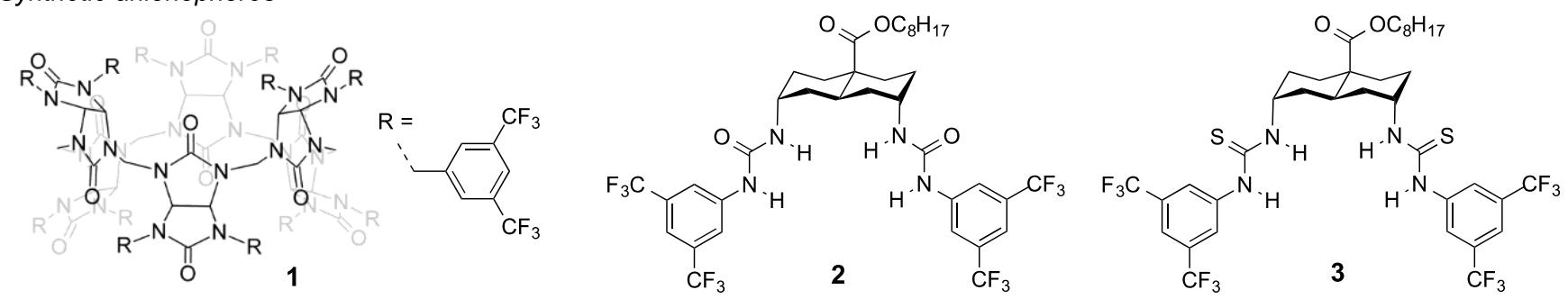

Commercial ionophores

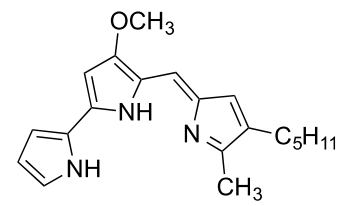

Prodigiosin, 4

$\mathrm{H}^{+} \mathrm{A}^{-}$symport

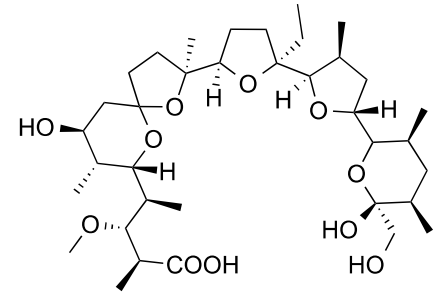

Monensin (Mon)

$\mathrm{H}^{+} / \mathrm{M}^{+}$antiport

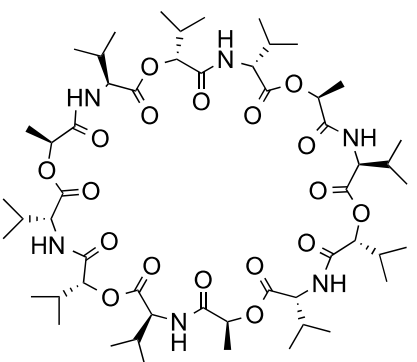

Valinomycin (Val)

$\mathrm{K}^{+}$uniport

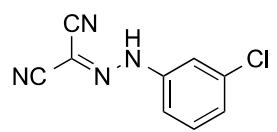

CCCP

$\mathrm{H}^{+}$uniport

Scheme 1 Structures of the different ionophores used in this study.

\section{Results \& Discussion}

\section{An emission assay to monitor transport of bicarbonate directly}

The cationic Eu(III) complex [Eu. $\left.\mathrm{L}^{1}\right]^{+}$(Fig. 1c) is based on a cyclen core possessing two pendant quinoline arms that absorb UV light around $330 \mathrm{~nm}$, allowing efficient energy transfer to the central Eu(III) ion, which emits light in the visible range $570-720 \mathrm{~nm}$. The Eu(III) probe has an open coordination site, occupied by a single water molecule in aqueous solution which quenches the Eu(III) emission significantly. In the presence of $\mathrm{HCO}_{3}{ }^{-}$, the coordinated water molecule is displaced upon binding of the hard oxyanion, resulting in a large enhancement in emission intensity (especially around $615 \mathrm{~nm}$ ) and changes in spectral form (Fig. 1a). ${ }^{39}$ The probe binds to the $\mathrm{HCO}_{3}{ }^{-}$with high selectivity over poorly coordinating anions that are commonly used in anion transport assays, including $\mathrm{Cl}^{-}$and $\mathrm{NO}_{3}{ }^{-}$. The complex is also sensitive to hydroxide ions, and thus to $\mathrm{pH}$, but this can be controlled with the help of a buffer as discussed later.

In order to use $\left[\mathrm{Eu} . \mathrm{L}^{1}\right]^{+}$to monitor the transport of $\mathrm{HCO}_{3}{ }^{-}$, we encapsulated this probe into large unilamellar vesicles (LUVs) consisting of the POPC and cholesterol in a 7:3 ratio and extruded these liposomes through a membrane with $200 \mathrm{~nm}$ pores, to obtain LUVs with an average hydrodynamic diameter of $183 \mathrm{~nm}$ (Fig. S2). Liposomes of this diameter are routinely used for transport experiments by emission spectroscopy and can be prepared reliably with a high degree of unilamellarity, in contrast to much larger vesicles, as used in the ${ }^{13} \mathrm{C}$ NMR assay. An aqueous solution of $225 \mathrm{mM} \mathrm{NaCl}$ was used both interior and exterior to facilitate $\mathrm{HCO}_{3}{ }^{-} / \mathrm{Cl}^{-}$exchange (antiport) process and $5 \mathrm{mM}$ HEPES buffer was added and adjusted to $\mathrm{pH} 7.0$ (Fig. 1C). Anionophore 1 was preincorporated in the membrane of the

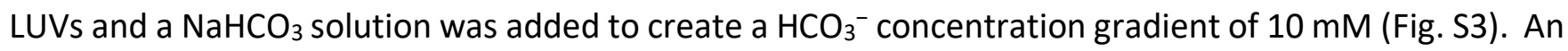
increase in the intensity of the different emission bands of $\left[E u . L^{1}\right]^{+}$was observed (Fig. 1a) upon the addition of $\mathrm{NaHCO}_{3}$. We chose to monitor the $\Delta J=2$ emission band around $615 \mathrm{~nm}$ (see Fig. $1 \mathrm{~b}$ ), as this showed the strongest increase (Fig. 1a), in agreement with observations in titrations of [Eu. $\left.\mathrm{L}^{1}\right]^{+}$with $\mathrm{HCO}_{3}{ }^{-39}$ From here on, we will refer to these experimental conditions as the EuL1 assay. 
a.

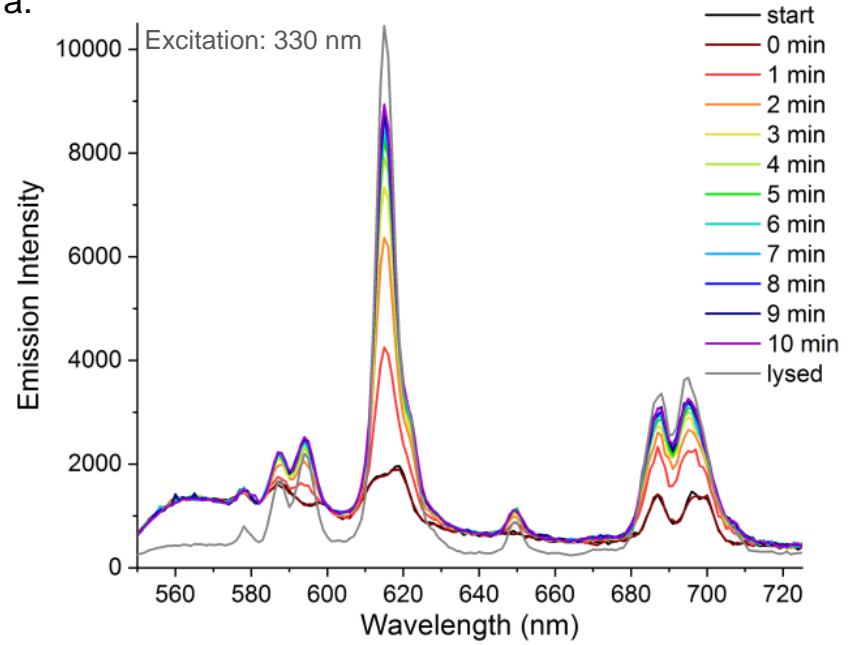

c.

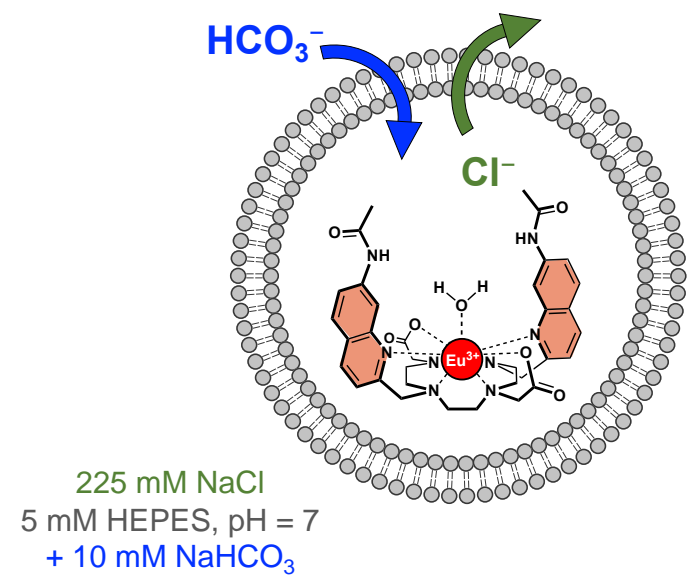

b.

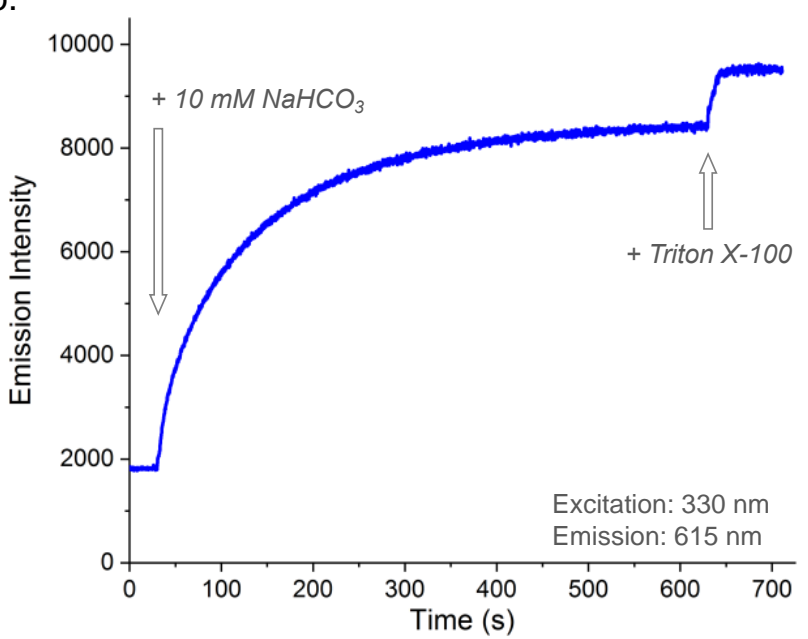

d.

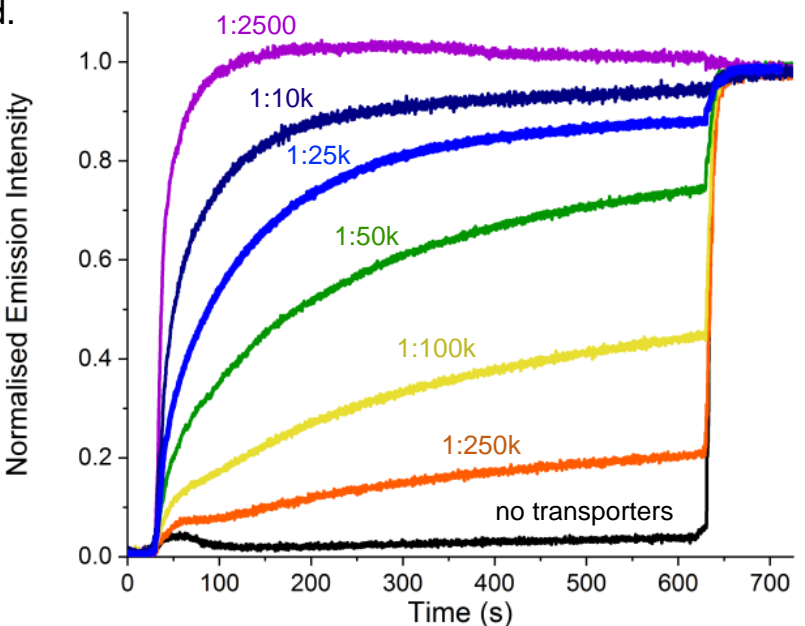

Fig. 1 Transport of $\mathrm{HCO}_{3}{ }^{-}$by anionophore 1 preincorporated in LUVs with the probe [Eu. $\left.\mathrm{L}^{1}\right]^{+}$encapsulated $(50 \mu \mathrm{M})$, suspended in $225 \mathrm{mM} \mathrm{NaCl}$ with $5 \mathrm{mM} \mathrm{HEPES}$ at pH 7.0 (interior and exterior), upon addition of $10 \mathrm{mM} \mathrm{NaHCO}$ after 30 seconds and lysis of the LUVs after 10 minutes. a. Emission spectra of [Eu. $\left.L^{1}\right]^{+}$recorded during the transport by $\mathbf{1}$ (at 1:25k transporter to lipid ratio); b. Emission intensity at $615 \mathrm{~nm}$ monitored over time for the transport as in a.; c. Schematic representation of EuL1 assay to study transport of $\mathrm{HCO}_{3}^{-}$; d. Normalised transport curves for anionophore 1 preincorporated at various anionophore to lipid ratios.

The increase in the emission intensity over time upon the addition of $\mathrm{NaHCO}_{3}$ indicates that $\mathrm{HCO}_{3}{ }^{-}$has entered the liposomes. Since hardly any change in the emission intensity was observed in the absence of anionophore 1 (Fig. $1 \mathrm{~d}$, black curve), we can conclude that bambusuril 1 transports $\mathrm{HCO}_{3}{ }^{-}$into the liposomes and that the new EuL1 assay allows to monitor this process.

The concentration of 1 that was preincorporated into the liposomes was varied from one bambusuril per 250,000 lipids (Fig. 1d, orange curve) to one per 2500 lipids (Fig. 1d, purple curve) and a clear increase in the rate of transport was observed for increasing concentrations of anionophore 1 . This shows that the EuL1 assay is highly sensitive and can be used to study the kinetics of $\mathrm{HCO}_{3}{ }^{-}$transport. Furthermore, these results reinforce our previous findings that bambusuril 1 is a very potent $\mathrm{HCO}_{3}{ }^{-} / \mathrm{Cl}^{-}$transporter, ${ }^{24}$ showing activity at 1:250k ratio, which corresponds to an average of two bambusurils per LUV. 


\section{Apparent transport of bicarbonate by cationophores}

During our initial experiments to develop the EuL1 assay to study the transport of bicarbonate, we noticed that not only liposomes with anionophores gave an increase in emission intensity, but that also the addition of monensin to the LUVs gave a clear response (Fig. 2, red curve). Furthermore, we noticed that monensin also gives a positive response in the ${ }^{13} \mathrm{C} \mathrm{NMR}$ assay for $\mathrm{HCO}_{3}{ }^{-} / \mathrm{Cl}^{-}$transport (see ESI Section 4). ${ }^{11}$ Monensin is a well-known cationophore, ${ }^{41,42,43}$ that can wrap around cations, using its $\mathrm{O}$ atoms to interact. ${ }^{44}$ It is not likely that this compound, nor its complex with $\mathrm{Na}^{+}$or $\mathrm{K}^{+}$, can bind bicarbonate sufficiently strongly to cause transport. Valinomycin, another well know cationophore, was also tested in the EuL1 assay, but showed a much smaller response (Fig. 2, blue curve), indicating that $\mathrm{M}^{+} \mathrm{HCO}_{3}{ }^{-}$ion pairs are not readily transported by cationophores, as expected.

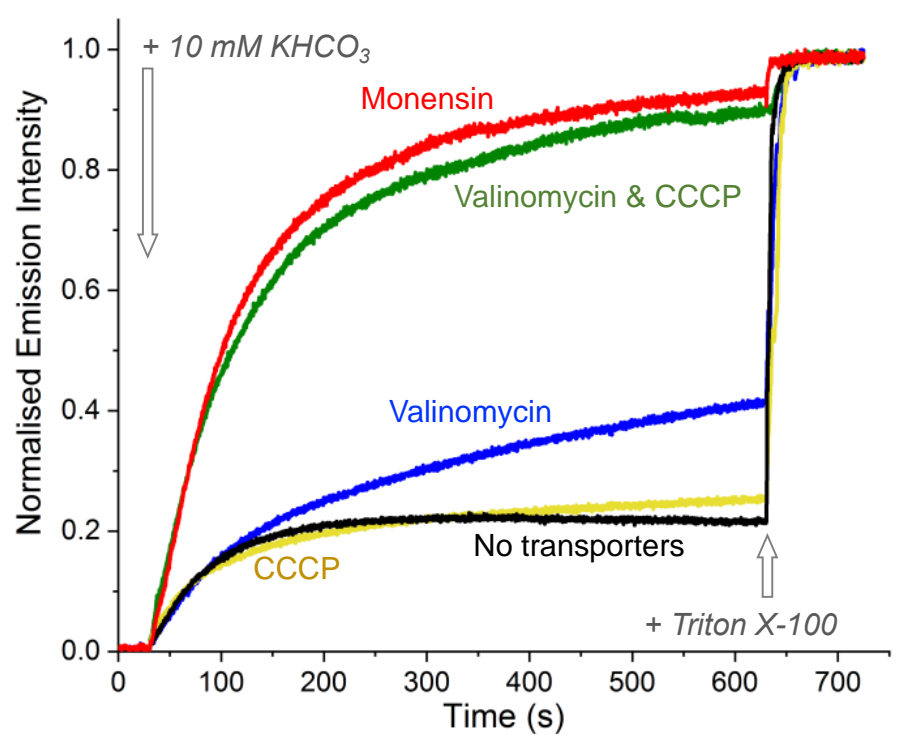

Fig. 2 Transport as monitored by the EuL1 assay in $112 \mathrm{mM} \mathrm{K}_{2} \mathrm{SO}_{4}$ with $5 \mathrm{mM} \mathrm{HEPES}$ at pH 7, upon addition of $10 \mathrm{mM} \mathrm{KHCO}_{3}$ after 30 seconds. Different cation transporters were added to the LUVs at a transporter to lipid ratio of 1:1000.

However, when studying the transport of $\mathrm{HCO}_{3}{ }^{-}$, we should take into account that addition of a pulse of $\mathrm{MHCO}_{3}$ to the exterior of the liposomes does not only create a gradient of $\mathrm{HCO}_{3}{ }^{-}$, but also of its conjugate acid $\mathrm{H}_{2} \mathrm{CO}_{3}{ }^{17}$ and of $\mathrm{CO}_{2}$, formed upon dehydration. ${ }^{45}$ We should note that at equilibrium the concentration of $\mathrm{CO}_{2}$ is almost 1000 -fold higher than that of $\mathrm{H}_{2} \mathrm{CO}_{3}$ in aqueous salt solutions. ${ }^{46}$ Furthermore, it is well known that $\mathrm{CO}_{2}$ can diffuse spontaneously across the membranes of cells which play important roles in $\mathrm{HCO}_{3}{ }^{-}$homeostasis, ${ }^{47}$ such as red blood cells and renal epithelial cells. ${ }^{2}$

$$
\begin{gathered}
\mathrm{HCO}_{3}{ }^{-}+\mathrm{H}^{+} \rightleftharpoons \underset{\mathrm{H}}{\mathrm{H}} \mathrm{CO}_{3} \\
\mathbb{\mathrm { CO } _ { 2 }}+\mathrm{H}_{2} \mathrm{O}
\end{gathered}
$$

We should thus consider the possibility that $\mathrm{CO}_{2}$ diffuses across the membranes of our liposomes, upon the addition of the $\mathrm{MHCO}_{3}$ pulse. This increase of the concentration of $\mathrm{CO}_{2}$ inside the liposomes would result in an acidification of the interior, causing a $\mathrm{pH}$ gradient to build up, which will stop the diffusion of $\mathrm{CO}_{2}$. However, in the presence of an ionophore which can transport protons to prevent the build-up of a pH gradient, the diffusion of $\mathrm{CO}_{2}$ can continue until the $\mathrm{CO}_{2}$ gradient has been dissipated. Inside the liposomes, the diffused $\mathrm{CO}_{2}$ will establish equilibria with its hydrate $\mathrm{H}_{2} \mathrm{CO}_{3}$ and the deprotonated form $\mathrm{HCO}_{3}{ }^{-}$. The formation of this bicarbonate anion is observed as a positive luminescence response of the EuL1 assay (Fig. 2, red curve). Thus, the diffusion of $\mathrm{CO}_{2}$ into the LUVs (giving $\mathrm{H}_{2} \mathrm{CO}_{3}$ ) combined with ionophore facilitated transport of $\mathrm{H}^{+}$out of the LUVs, results in a net transport of $\mathrm{HCO}_{3}{ }^{-}$. 
When studying transmembrane transport processes in LUVs, transport of charges should be balanced to avoid an electric potential from building up. Transport of $\mathrm{HCO}_{3}{ }^{-}$into LUVs can be balanced by transport of another anion out of the LUVs (Fig. 3, mechanism A). When $\mathrm{CO}_{2}$ diffuses into LUVs and acidification is prevented by transport of protons out of the LUVs, this charge transport has to be balanced by either the transport of cations into the LUVs (Fig. 3, mechanism B) or transport of anions out of the LUVs (Fig 3 , mechanism C). Alternatively, acidification by $\mathrm{CO}_{2}$ diffusion can be prevented by hydroxide transport into the LUVs, balanced by transport of other anions out of the LUVs (Fig 3, mechanism D), which can often not be distinguished from mechanism $C$.

A

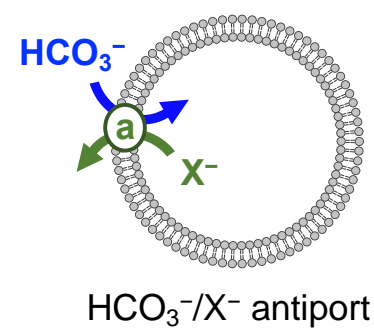

B

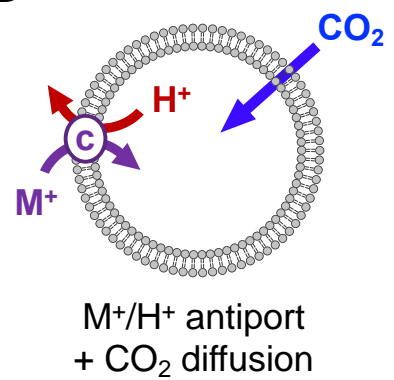

C

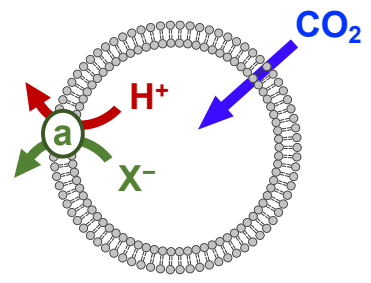

$\mathrm{H}^{+} / \mathrm{X}^{-}$symport $+\mathrm{CO}_{2}$ diffusion
D

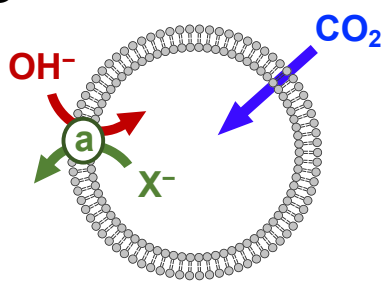

$\mathrm{OH}^{-} / \mathrm{X}^{-}$antiport $+\mathrm{CO}_{2}$ diffusion

Fig. 3 Different mechanisms by which apparent transport of $\mathrm{HCO}_{3}{ }^{-}$could occur. In mechanism $\mathrm{A}$, anionophore (a) exchanges $\mathrm{HCO}_{3}{ }^{-}$for another anion. Mechanisms B-D rely on the diffusion of $\mathrm{CO}_{2}$ coupled to transport of $\mathrm{H}^{+}$or $\mathrm{OH}^{-}$by cationophores (c) or anionophores to result in the net transport of $\mathrm{HCO}_{3}{ }^{-}$, without this anion crossing the membrane.

Monensin is well known to efficiently exchange protons with $\mathrm{Na}^{+}$or $\mathrm{K}^{+}$cations $\left(\mathrm{H}^{+} / \mathrm{M}^{+}\right.$antiport $),{ }^{41}$ dissipating $\mathrm{pH}$ gradients and thus compensating for $\mathrm{CO}_{2}$ diffusion, resulting in the apparent transport of $\mathrm{HCO}_{3}{ }^{-}$that the red curve in Fig. 2 indicates, following mechanism B. In contrast, valinomycin performs electrogenic transport of $\mathrm{K}^{+}$, but is not capable of transporting protons via $\mathrm{H}^{+} / \mathrm{M}^{+}$antiport, ${ }^{48}$ thus preventing diffusion of $\mathrm{CO}_{2}$. The protonophore carbonyl cyanide 3-chlorophenylhydrazone (CCCP) is known to transport protons, but no other cations. ${ }^{49}$ Adding CCCP to the EuL1 assay did not result in a response (Fig. 2, yellow curve), but adding both valinomycin and CCCP to the LUVs in $\mathrm{K}_{2} \mathrm{SO}_{4}$ solution gave apparent $\mathrm{HCO}_{3}{ }^{-}$transport with similar rates as monensin (Fig. 2, green curve), via a similar mechanism. In this case, the acidification by $\mathrm{CO}_{2}$ diffusion is prevented by CCCP transporting protons out of the LUVs, while valinomycin transports $\mathrm{K}^{+}$into the LUVs for charge balance. Also, the ion channel gramicidin, which is capable of transporting various cations, including $\mathrm{H}^{+}, \mathrm{Na}^{+}$, and $\mathrm{K}^{+}$, can give apparent $\mathrm{HCO}_{3}{ }^{-}$transport via mechanism B (Fig. S4).

To confirm that the apparent transport of $\mathrm{HCO}_{3}{ }^{-}$by monensin ${ }^{17}$ as observed in the EuL1 assay is indeed caused by mechanism $B$, the conditions of the assay were varied. Neither the $\mathrm{CO}_{2}$ diffusion nor the $\mathrm{H}^{+} / \mathrm{M}^{+}$ antiport would involve the anion $\mathrm{X}^{-}$, thus variations of the anion would not be expected to significantly impact the rate of apparent $\mathrm{HCO}_{3}{ }^{-}$transport. Indeed, monensin gives similar transport curves in $\mathrm{MCl}$, $\mathrm{MNO}_{3}$, and $\mathrm{M}_{2} \mathrm{SO}_{4}$ solutions (where $\mathrm{M}^{+}$is $\mathrm{Na}^{+}$or $\mathrm{K}^{+}$, see Fig. $\mathrm{S} 5$ and 4a). No systematic differences were observed between the experiments in sodium and in potassium salts. This could mean either that monensin performs $\mathrm{H}^{+} / \mathrm{Na}^{+}$and $\mathrm{H}^{+} / \mathrm{K}^{+}$antiport at identical rates, or that the formation ${ }^{45}$ and diffusion of $\mathrm{CO}_{2}$ are rate limiting in mechanism $\mathrm{B}$. To distinguish between these options, we varied the concentration of monensin. While decreasing the monensin to lipid ratio from 1:1000 to 1:10,000 gave a lower rate of transport, increasing to a ratio of 1:100 did not significantly impact the rate of transport (Fig. S6). This confirms that the diffusion of $\mathrm{CO}_{2}$ is rate limiting in the apparent transport of $\mathrm{HCO}_{3}{ }^{-}$and not the $\mathrm{H}^{+} / \mathrm{M}^{+}$ antiport by monensin.

Considering that the role of monensin in the proposed transport process is to prevent the formation of a $\mathrm{pH}$ gradient upon $\mathrm{CO}_{2}$ diffusion, we may expect that in the absence of any transporters the concentration of the buffer and the $\mathrm{pH}$ at which the experiments are performed determine how much 
$\mathrm{CO}_{2}$ can diffuse into the LUVs before the $\mathrm{pH}$ gradient stops this process. When controls for transport experiments were performed by adding $10 \mathrm{mM} \mathrm{NaHCO}_{3}$ to LUVs in $20 \mathrm{mM} \mathrm{HEPES}$ at a starting pH of 7.6, the external $\mathrm{pH}$ increased to 7.7 and a much larger apparent influx of $\mathrm{HCO}_{3}{ }^{-}$was observed (Fig. S7) than when working with $5 \mathrm{mM} \mathrm{HEPES}$ at $\mathrm{pH} 7.0$ (where addition of $10 \mathrm{mM} \mathrm{NaHCO}_{3}$ increases the $\mathrm{pH}$ to 7.4). HEPES has a $\mathrm{pK}_{\mathrm{a}}$ of 7.5 and the optimal buffer range is reported to be $6.8-8.2,{ }^{50}$ thus the higher concentration of HEPES can compensate the effect of the acidification by $\mathrm{CO}_{2}$ influx. When $20 \mathrm{mM} \mathrm{HEPES}$ was used but starting at $\mathrm{pH} 6.5$, the buffer could not compensate for the acidification and hardly any $\mathrm{CO}_{2}$ diffusion was observed (Fig. S8).

To verify if the $\mathrm{pH}$ inside the LUVs changes as expected upon diffusion of $\mathrm{CO}_{2}$ (in absence of ionophores) or upon dissipation of the $\mathrm{pH}$ gradient by monensin, transport experiments were performed in which the $\mathrm{pH}$ sensitive probe HPTS was encapsulated instead of the bicarbonate sensitive probe $\left[\mathrm{Eu} . \mathrm{L}^{1}\right]^{+}$. All other conditions were identical to those used in the EuL1 assay (i.e., $225 \mathrm{mM} \mathrm{NaCl}, 5 \mathrm{mM} \mathrm{HEPES}, \mathrm{pH}$ 7.0). The results in Fig. 4d indeed show that the addition of $10 \mathrm{mM} \mathrm{NaHCO}_{3}$ to LUVs with monensin (1:1000 ratio) results in a rapid increase of the $\mathrm{pH}$ (red curve), indicating the equilibration of the $\mathrm{pH}$ gradient caused by the addition of the basic solution of $\mathrm{NaHCO}_{3}$. In contrast, addition of $\mathrm{NaHCO}_{3}$ to LUVs without transporters results in an acidification of the interior (black curve), in agreement with the formation of carbonic acid upon diffusion of $\mathrm{CO}_{2}$. LUVs with a very low concentration of monensin (1:50k) show an initial acidification of the interior due to $\mathrm{CO}_{2}$ diffusion, followed by a slow increase of the $\mathrm{pH}$ due to the $\mathrm{H}^{+} / \mathrm{Na}^{+}$antiport by monensin. These experiments with HPTS thus confirm that the apparent transport of $\mathrm{HCO}_{3}{ }^{-}$by monensin can be attributed to mechanism $\mathrm{B}$, permitted by dissipation of the $\mathrm{pH}$ gradient. Furthermore, these data show that the $\mathrm{pH}$ equilibration by monensin at 1:1000 ratio (Fig. 4d) is much faster than the apparent $\mathrm{HCO}_{3}{ }^{-}$transport revealed by the EuL1 assay (Fig. 4a), which is further proof that $\mathrm{CO}_{2}$ diffusion (and/or formation ${ }^{45}$ ) is rate limiting in the net transport of $\mathrm{HCO}_{3}{ }^{-}$by monensin (at 1:1000 ratio).
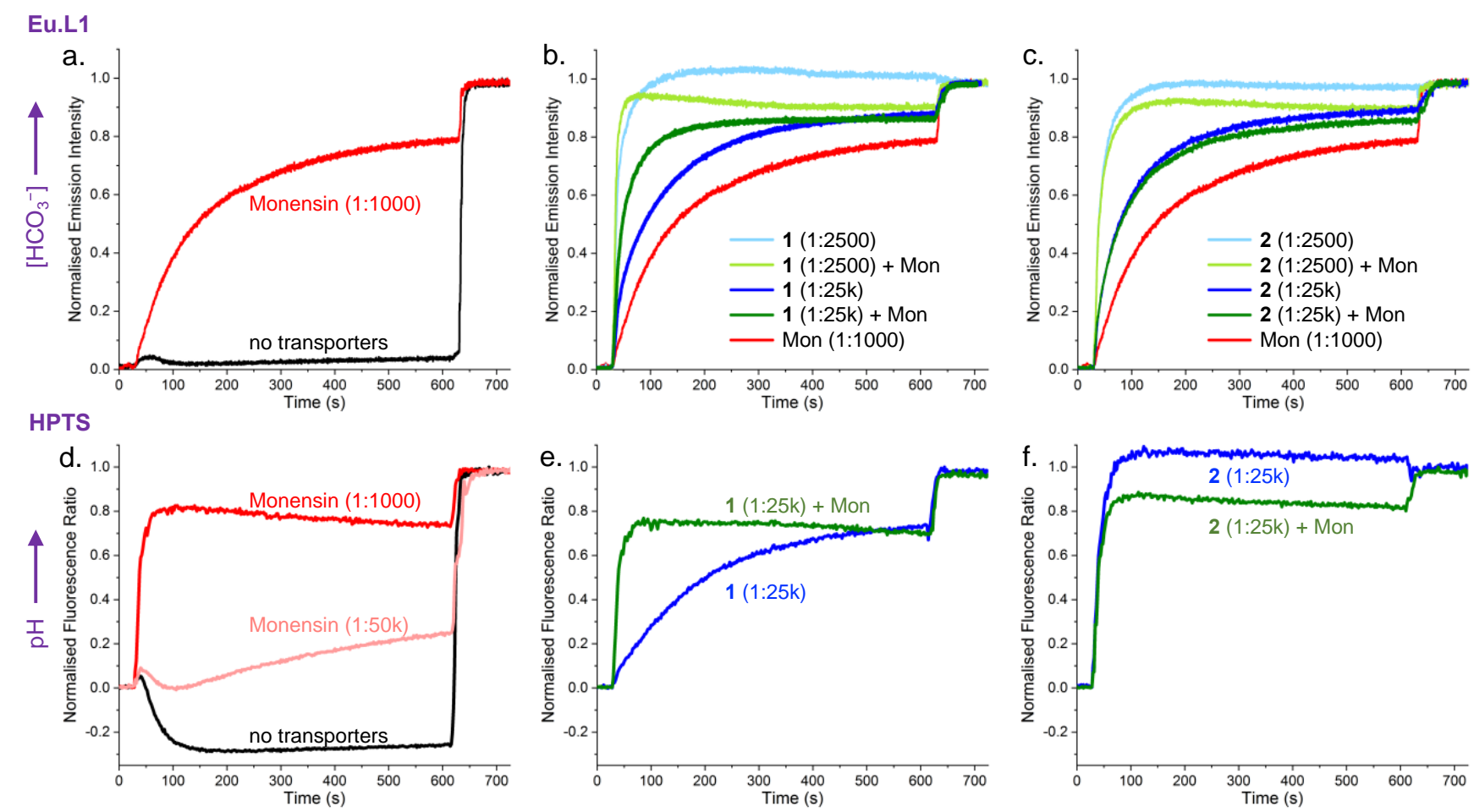

Fig. 4 Transport by monensin (a,d), bambusurils $\mathbf{1}(\mathrm{b}, \mathrm{e})$ and urea $\mathbf{2}(\mathrm{c}, \mathrm{f})$ as monitored by the EuL1 assay $(\mathrm{a}-\mathrm{c})$ or by the pH sensitive probe HPTS (d-f) in $225 \mathrm{mM} \mathrm{NaCl}$ with $5 \mathrm{mM} \mathrm{HEPES}$ at pH 7, upon addition of $10 \mathrm{mM} \mathrm{NaHCO}_{3}$ after 30 seconds and lysis of the LUVs 10 minutes after that. Monensin (1:1000 transporter to lipid ratio) was added to the experiments with anionophores 1 and 2. 
Analysis of the transport mechanisms by the different anionophores

Following experiments with bambusuril 1 and the various cationophores, we have studied the transport by anionophores 2-4 in the EuL1 assay in $\mathrm{NaCl}$ (blue curves in Fig. 4c and S9). A clear increase of the emission intensity was observed for all anionophores, even at the relatively low concentration of 1:25,000 (transporter to lipid ratio), indicating efficient $\mathrm{HCO}_{3}{ }^{-}$transport.

However, having observed that monensin and other cation transporters capable of dissipating $\mathrm{pH}$ gradients can show apparent $\mathrm{HCO}_{3}{ }^{-}$transport in the EuL1 assay, without actually transporting the $\mathrm{HCO}_{3}{ }^{-}$ anion, we have to consider if the observed transport by anionophores 1-4 is caused by $\mathrm{HCO}_{3}^{-} / \mathrm{Cl}^{-}$antiport (mechanism A), or whether other mechanisms could give a similar response. Gale and co-workers have clearly demonstrated that many urea and thiourea based receptors not only transport anions such as $\mathrm{Cl}^{-}$ (and $\mathrm{NO}_{3}^{-}$), but are also capable of dissipating $\mathrm{pH}$ gradients via $\mathrm{H}^{+} \mathrm{Cl}^{-}$symport or $\mathrm{OH}^{-} / \mathrm{Cl}^{-}$antiport processes (which can generally not be distinguished). ${ }^{51}$ These processes would prevent acidification of the interior of LUVs upon diffusion of $\mathrm{CO}_{2}$, as shown in Fig. 3 mechanisms $\mathrm{C}$ and D. This implies that anionophores could show apparent $\mathrm{HCO}_{3}{ }^{-}$transport that originates from $\mathrm{CO}_{2}$ diffusion and proton or hydroxide transport, in a similar way as observed for monensin.

To distinguish between the $\mathrm{HCO}_{3}{ }^{-} / \mathrm{Cl}^{-}$antiport mechanism $\mathrm{A}$ versus the $\mathrm{pH}$ equilibration mechanisms $\mathrm{C}$ and $D$, we should firstly consider if anionophores are capable of performing $\mathrm{H}^{+} \mathrm{Cl}^{-}$symport or $\mathrm{OH}^{-} / \mathrm{Cl}^{-}$ antiport. Bambusuril 1 cannot be readily protonated nor deprotonated, processes that would favour $\mathrm{H}^{+}$ transport. We have previously shown that bambusuril 1 is indeed not able to dissipate $\mathrm{pH}$ gradients in the presence of $\mathrm{Cl}^{-}$or $\mathrm{NO}_{3}{ }^{-}$, and thus is incapable of $\mathrm{H}^{+} \mathrm{Cl}^{-}$symport and $\mathrm{OH}^{-} / \mathrm{Cl}^{-}$antiport. ${ }^{24}$ Indeed, when monitoring the $\mathrm{pH}$ changes inside the liposomes with bambusuril 1 upon addition of $\mathrm{NaHCO}_{3}$ (blue curve in Fig. 4e), a gradual increases in $\mathrm{pH}$ is observed, resembling the kinetics of the transport of the basic $\mathrm{HCO}_{3}{ }^{-}$anion into the LUVs (blue curve in Fig. 4b). Having excluded mechanisms $\mathrm{C}$ and $\mathrm{D}$, we can conclude that the transport observed by bambusuril 1 takes place via $\mathrm{HCO}_{3}{ }^{-} / \mathrm{Cl}^{-}$antiport (mechanism A).

In contrast to bambusuril 1, prodigiosin 4 is a well-known $\mathrm{HCl}$ transporter, as the pyrrole ring is readily protonated. ${ }^{52,53}$ Decalin bis-urea $\mathbf{2}$ and bis-thiourea $\mathbf{3}$ both have phenyl rings with electron withdrawing substituents, resulting in relatively acidic (thio)urea $\mathrm{N}-\mathrm{H}$ groups, making them good candidates for $\mathrm{HCl}$ symport or $\mathrm{OH}^{-} / \mathrm{Cl}^{-}$antiport. ${ }^{51}$ When monitoring the $\mathrm{pH}$ inside the LUVs with compounds 2-4 upon addition of $\mathrm{NaHCO}_{3}$, a rapid equilibration of $\mathrm{pH}$ was observed (Fig. $4 \mathrm{f}$ and $\mathrm{S} 18$, blue curves). This $\mathrm{pH}$ equilibration is much faster than the response by the same concentration of these compounds in the EuL1 assay (Fig. 4c and S9), resembling the effect by monensin (Fig. 4d). This demonstrates that compounds 2-4 indeed perform $\mathrm{HCl}$ symport or $\mathrm{OH}^{-} / \mathrm{Cl}^{-}$antiport efficiently and that apparent $\mathrm{HCO}_{3}{ }^{-}$ transport by mechanisms $\mathrm{C}$ or $\mathrm{D}$ could take place.

To study if mechanisms $C$ or $D$ indeed take place, we have performed transport experiments in which we added monensin to LUVs with the anionophores (Fig. 4 and S9-11, green curves). For bambusuril 1, addition of monensin gives a clear increase in the rate of transport as seen from the comparison of the green to the blue curves in Fig $4 \mathrm{~b}$ and S11. This increase can be understood from the combined effect of mechanism $A$ by 1 and mechanism $B$ by monensin, leading to a higher rate of net transport of $\mathrm{HCO}_{3}{ }^{-}$ than by either of these two processes alone. In contrast, addition of monensin to LUVs with anionophores 2-4 did not increase the rate of transport, as shown for $\mathbf{2}$ in Fig. 4c and for 3-4 in Fig. S11. We have seen that $\mathrm{pH}$ equilibration by these compounds is nearly instantaneous when incorporated at 1:25,000 transporter to lipid concentration, thus that $\mathrm{CO}_{2}$ diffusion would most likely be rate-limiting in mechanisms $C$ and $D$, as it was for monensin in mechanism $B$ (see above). If $\mathrm{CO}_{2}$ diffusion is rate-limiting in the transport by 2-4 via mechanisms $C$ and $D$, the addition of monensin will not have any impact on the overall rate of (apparent) $\mathrm{HCO}_{3}{ }^{-}$transport, as this will remain limited by $\mathrm{CO}_{2}$ diffusion. Thus, the fact that addition of monensin does not change the rate of transport by 2-4 does mean that these anionophores act via mechanism C or D. 
This brings us to question whether these compounds perform any $\mathrm{HCO}_{3}{ }^{-} / \mathrm{Cl}^{-}$transport (mechanism A) in addition to their transport by mechanisms $C$ and $D$. To test this, we have increased the concentrations of $\mathbf{2}$ and $\mathbf{3}$ that were preincorporated in the membranes of the liposomes to 1:2500 (transporter to lipid ratio). The light blue curves in Fig. $4 \mathrm{C}$ and S9a show that this ten-fold increase in transporter concentration indeed leads to a significantly faster rate of (apparent) $\mathrm{HCO}_{3}{ }^{-}$transport, and that this overall rate clearly exceeds rates of transport that are limited by $\mathrm{CO}_{2}$ diffusion (as observed in the curves for monensin $\geq 1: 1000$ ratio, see also Fig. S10). From this we can conclude that the transport observed by compounds 2 and $\mathbf{3}$ in the EuL1 assay results from the combination of $\mathrm{HCO}_{3}{ }^{-} / \mathrm{Cl}^{-}$antiport mechanism A with $\mathrm{CO}_{2}$ diffusion mechanism $\mathrm{C}$ or $\mathrm{D}$. These compounds dissipate the $\mathrm{pH}$ gradient faster than they transport $\mathrm{HCO}_{3}{ }^{-}$and as a result $\mathrm{C}$ or $\mathrm{D}$ is the main mechanism, up to the point that $\mathrm{CO}_{2}$ diffusion becomes rate limiting, after which mechanism $A$ contributes to the net $\mathrm{HCO}_{3}{ }^{-}$transport.

Table 1 Performance of anionophores 1-3 and prodigiosin in the EuL1 assay in $\mathrm{NaCl}$ and $\mathrm{NaNO}_{3}$.

\begin{tabular}{|c|c|c|c|c|c|c|}
\hline \multirow[t]{2}{*}{ Salt } & \multirow[t]{2}{*}{$\begin{array}{l}\text { Aniono- } \\
\text { phore }\end{array}$} & \multirow{2}{*}{$\begin{array}{l}\text { Concentration } \\
\text { (anionophore:lipid) }\end{array}$} & \multicolumn{2}{|c|}{$\begin{array}{l}\text { Transport } \\
\text { (without monensin) }\end{array}$} & \multicolumn{2}{|c|}{$\begin{array}{l}\text { Transport } \\
\text { (with monensin) }^{c}\end{array}$} \\
\hline & & & $\begin{array}{l}\text { Half-life } \\
(s)^{\mathrm{a}}\end{array}$ & $\begin{array}{l}\text { Initial } \\
\text { rate }\left(s^{-1}\right)^{b}\end{array}$ & $\begin{array}{l}\text { Half-life } \\
(s)^{\mathrm{a}}\end{array}$ & $\begin{array}{l}\text { Initial } \\
\text { rate }\left(\mathrm{s}^{-1}\right)^{\mathrm{b}}\end{array}$ \\
\hline \multirow[t]{12}{*}{$\mathrm{NaCl}$} & None & & * & * & 82 & 0.008 \\
\hline & 1 & $1: 2500$ & 10 & 0.124 & 4 & 0.178 \\
\hline & & $1: 10 \mathrm{k}$ & 32 & 0.041 & 17 & 0.059 \\
\hline & & $1: 25 \mathrm{k}$ & 64 & 0.026 & 21 & 0.051 \\
\hline & & 1:50k & 110 & 0.015 & 40 & 0.025 \\
\hline & & 1:100k & $*$ & $*$ & 58 & 0.015 \\
\hline & & $1: 250 \mathrm{k}$ & $*$ & $*$ & 83 & 0.009 \\
\hline & 2 & $1: 2500$ & 12 & 0.093 & 11 & 0.091 \\
\hline & & $1: 25 \mathrm{k}$ & 51 & 0.019 & 50 & 0.017 \\
\hline & 3 & $1: 2500$ & 12 & 0.077 & 11 & 0.071 \\
\hline & & $1: 25 \mathrm{k}$ & 46 & 0.021 & 47 & 0.020 \\
\hline & 4 & $1: 25 \mathrm{k}$ & 59 & 0.012 & 74 & 0.012 \\
\hline \multirow[t]{8}{*}{$\mathrm{NaNO}_{3}$} & None & & $*$ & $*$ & 81 & 0.008 \\
\hline & 1 & $1: 2500$ & $*$ & $*$ & 67 & 0.009 \\
\hline & & $1: 25 \mathrm{k}$ & $*$ & $*$ & 85 & 0.007 \\
\hline & 2 & $1: 2500$ & 45 & 0.021 & 40 & 0.022 \\
\hline & & $1: 25 \mathrm{k}$ & 89 & 0.007 & 85 & 0.007 \\
\hline & 3 & $1: 2500$ & 16 & 0.060 & 14 & 0.052 \\
\hline & & $1: 25 \mathrm{k}$ & 65 & 0.014 & 59 & 0.013 \\
\hline & 4 & $1: 25 \mathrm{k}$ & 61 & 0.012 & 68 & 0.011 \\
\hline
\end{tabular}

a Calculated from a single exponential fit of the transport curve, see ESI for details.

${ }^{b}$ Calculated from a double exponential fit of the transport curve, see ESI for details.

c Transport in presence of monensin at a 1:1000 monensin to lipid ratio.

* Transport was absent or too slow to quantify. 


\section{Quantitative comparison of rates of transport}

To verify the qualitative trends and comparisons described above, we have fitted the transport data from the EuL1 assay with single and double exponential functions, to obtain half-lives and initial rates respectively (see ESI for details). The results are summarised in Table 1 . In $\mathrm{NaCl}$ solutions, the half-lives of transport by bambusuril 1 clearly decrease by a factor two or more when monensin is present (see also Fig. S12). In contrast, the half-lives by 2-4 are nearly identical. Similar trends are observed when comparing the initial rates.

When comparing initial rates of transport as measured in the EuL1 assay quantitively, we should consider the effect of the different $\mathrm{pH}$ profiles during the transport measurements (Fig. $4 \mathrm{~d}-\mathrm{f}$ ), as the [Eu. $\left.\mathrm{L}^{1}\right]^{+}$probe is not only sensitive to concentrations of $\mathrm{HCO}_{3}{ }^{-}$, but also to $\mathrm{pH} .{ }^{39}$ While the effects of $\mathrm{pH}$ on the emission intensity were reported to be small at $\mathrm{pH} \leq 8,{ }^{39}$ the $\mathrm{pH}$ has a more noticeable effect on the increase of luminescence observed upon addition of $\mathrm{HCO}_{3}{ }^{-}$. The titrations in Fig. S13-14 show that this increase of emission intensity is larger at $\mathrm{pH} 7.4$ than at $\mathrm{pH}$ 7.0, leading to different apparent affinities of EuL1 for $\mathrm{HCO}_{3}{ }^{-}$. In the presence of monensin, the $\mathrm{pH}$ rapidly equilibrates to $\sim 7.4$ (Fig. $4 \mathrm{e}$, green curve), thus resulting in a higher sensitivity of the probe to $\mathrm{HCO}_{3}{ }^{-}$, which could result in a higher apparent initial rate compared to transport measured under conditions without pH equilibration (i.e., with only 1 present in the LUVs).

Based on the discussion of the additivity of mechanisms $A$ and $B$, we could have expected that initial rates of transport by 1 (at different concentrations) and by monensin alone (1:1000 ratio) could be added to predict the initial rates of transport by the combination of 1 and monensin. However, in Table 1 we see that the values found are higher than those predicted by this hypothesis, especially at higher concentrations of $\mathbf{1}$ ( $\geq 1: 25 \mathrm{k}$ ratio). This could be explained by the effects of the $\mathrm{pH}$ on the initial rates, as discussed above. Furthermore, the normalisation of the data could result in an error on the values of the initial rates, but not the half-lives. Therefore, half-lives are more reliable to compare transport data of 1 in presence and absence of monensin, as these values indicate how fast equilibrium is reached, independent of absolute emission values. The comparison of half-lives of transport by 1 with and without monensin clearly shows that equilibrium is reached much faster in the presence of monensin (Table 1 and Fig. S12), confirming the additivity of mechanisms A and B.

Table 1 also shows that the overall rates of apparent $\mathrm{HCO}_{3}{ }^{-}$transport by anionophores 1-4 (in absence of monensin) are rather similar. However, the different $\mathrm{pH}$ profiles will affect this comparison and it would thus be better to compare the different transporters in the presence of monensin. Under those conditions, $\mathrm{CO}_{2}$ diffusion based mechanisms contribute to the transport for all the compounds, but as this process has a limited and thus constant rate, the differences in half-lives and initial rates between anionophores 1-4 (in presence of monensin) can be attributed to the difference in rates of $\mathrm{HCO}_{3}{ }^{-} / \mathrm{Cl}^{-}$ antiport by the anionophores. In this comparison, bambusuril $\mathbf{1}$ is clearly the most active ionophore for $\mathrm{HCO}_{3}{ }^{-} / \mathrm{Cl}^{-}$antiport. Bis-urea 2 and bis-thiourea $\mathbf{3}$ show similar rates of transport and are slightly more active than prodigiosin $\mathbf{4}$, for which the half-life is very close to that of transport by monensin alone.

\section{Bicarbonate transport experiments in $\mathrm{NaNO}_{3}$}

The newly developed EuL1 assay does not only allow the study of $\mathrm{HCO}_{3}{ }^{-} / \mathrm{Cl}^{-}$exchange, but can also be used to study the exchange of bicarbonate with other anions, such as nitrate. Commonly employed indirect methods to study $\mathrm{HCO}_{3}{ }^{-}$transport rely on the monitoring of $\mathrm{Cl}^{-}$concentrations and could thus not be used to study the exchange between $\mathrm{HCO}_{3}{ }^{-}$and $\mathrm{NO}_{3}{ }^{-}$, while $\left[\mathrm{Eu} . \mathrm{L}^{1}\right]^{+}$does not bind to either $\mathrm{Cl}^{-}$ or $\mathrm{NO}_{3}{ }^{-}$and could thus be used to monitor $\mathrm{HCO}_{3}{ }^{-} / \mathrm{NO}_{3}{ }^{-}$exchange in the same way as $\mathrm{HCO}_{3}{ }^{-} / \mathrm{Cl}^{-}$ exchange. ${ }^{39} \mathrm{Fig} .5$ shows the transport curves by anionophores 1-4 at 1:25,000 ratio in the EuL1 assay in $\mathrm{NaNO}_{3}$, and the curve of monensin (1:1000) is included for comparison. Results from experiments at different concentrations of ionophores, both in presence and absence of monensin, are included in Table 1 and Fig. S16. 


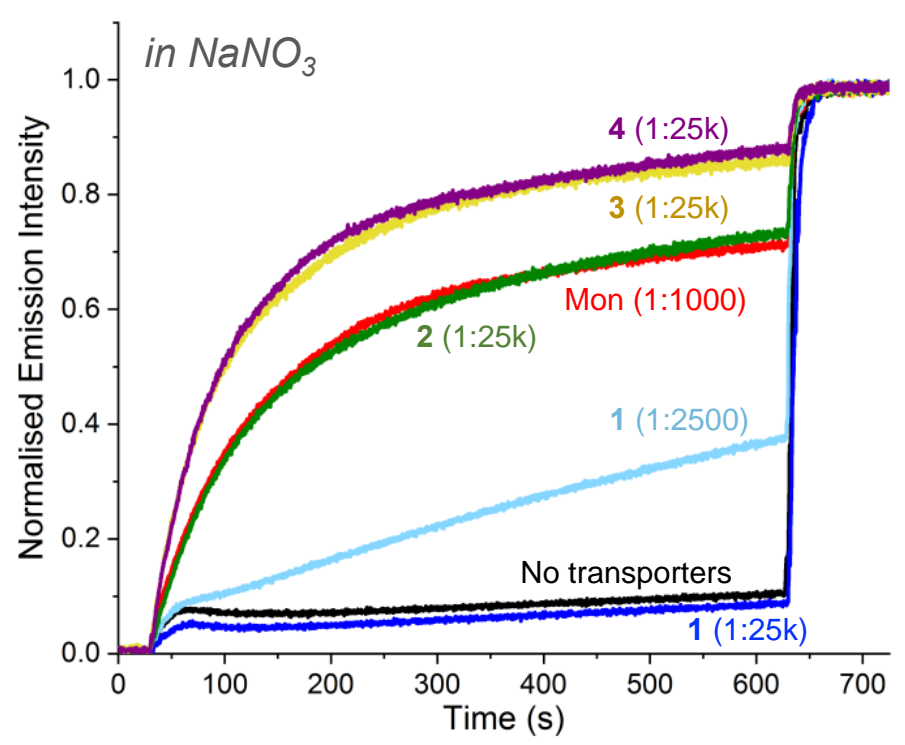

Fig. 5 Transport by anionophores 1-4 and monensin, as monitored by the EuL1 assay in $225 \mathrm{mM} \mathrm{NaNO} \mathrm{N}_{3}$ with 5 mM HEPES at $\mathrm{pH}$ 7, upon addition of $10 \mathrm{mM} \mathrm{NaHCO}_{3}$ after 30 seconds and lysis of the LUVs after 10 minutes.

Compounds 2-4 show efficient (apparent) transport of $\mathrm{HCO}_{3}{ }^{-}$in $\mathrm{NaNO}_{3}$ and rates do not change upon addition of monensin, similar to the results obtained for these compounds in $\mathrm{NaCl}$, indicating that the same combination of mechanisms applies. We note, however, that the overall $\mathrm{HCO}_{3}{ }^{-}$transport by 2 and 3 is somewhat less efficient in $\mathrm{NaNO}_{3}$ than in $\mathrm{NaCl}$, and that this difference is more pronounced for urea 2 than for thiourea 3. Gale et al. have reported that anionophores can display selectivity in transport for either $\mathrm{Cl}^{-}$or $\mathrm{NO}_{3}{ }^{-}$and that this selectivity can be correlated to the relative affinities for these anions. ${ }^{54}$ They found that compounds with the highest affinities were clearly more selective for $\mathrm{Cl}^{-}$over $\mathrm{NO}_{3}{ }^{-}$, both in binding and transport. ${ }^{55}$ It is thus not unsurprising that compounds $\mathbf{2}$ and $\mathbf{3}$, both efficient receptors for $\mathrm{Cl}^{-}$, could transport $\mathrm{Cl}^{-}$more easily than $\mathrm{NO}_{3}{ }^{-}$, resulting in higher rates of (apparent) $\mathrm{HCO}_{3}{ }^{-}$ transport in $\mathrm{NaCl}$ than in $\mathrm{NaNO}_{3}$.

In contrast to anionophores $\mathbf{2 - 4}$, bambusuril 1 showed no transport at a 1:25,000 ratio, and only very slow transport was observed when using a 10-fold higher concentration of 1 (1:2500, Fig. 5 light blue curve). This slow $\mathrm{HCO}_{3}{ }^{-} / \mathrm{NO}_{3}{ }^{-}$exchange by 1 resembles the results reported for $\mathrm{Cl}^{-} / \mathrm{NO}_{3}{ }^{-}$exchange, which was found to be 100 -fold slower than $\mathrm{Cl}^{-} / \mathrm{HCO}_{3}{ }^{-}$exchange by this bambusuril. ${ }^{24}$ We proposed that this large difference in rates of $\mathrm{Cl}^{-}$transport by 1 could be explained by a combination of two phenomena. Firstly, the very high affinity of 1 for $\mathrm{NO}_{3}^{-}\left(\mathrm{K}_{\mathrm{a}}=5 \times 10^{11} \mathrm{M}^{-1}\right.$ in acetonitrile) could prevent the release of this anion. Secondly, we postulated that the simultaneous binding of a $\mathrm{Cl}^{-}$and $\mathrm{a}^{-\mathrm{HCO}_{3}}{ }^{-}$anion in the bambusuril could facilitate the exchange of these anions. ${ }^{24}$ Even though the formation of an equivalent complex with $\mathrm{NO}_{3}{ }^{-}$and $\mathrm{HCO}_{3}{ }^{-}$simultaneously is possible, this does not appear to increase the rate of the exchange of these two anions. Instead, the very strong binding of $\mathrm{NO}_{3}{ }^{-}$is the most likely explanation for the low rates of $\mathrm{HCO}_{3}{ }^{-} / \mathrm{NO}_{3}{ }^{-}$exchange by 1 (see also Fig. S17).

Thus, when comparing the rates of apparent transport of $\mathrm{HCO}_{3}{ }^{-}$in $\mathrm{NaNO}_{3}$, thiourea 3 and prodigiosin 4 are the most efficient anionophores, followed closely by urea $\mathbf{2}$, while bambusuril $\mathbf{1}$ is clearly the least efficient transporter under these conditions. 


\section{Conclusions}

The results presented above demonstrate a new emission assay to directly monitor transport of $\mathrm{HCO}_{3}{ }^{-}$ into liposomes, using the encapsulated europium complex $\left[\mathrm{Eu} . \mathrm{L}^{1}\right]^{+}$, of which the luminescence increases upon binding $\mathrm{HCO}_{3}{ }^{-}$. This assay is highly sensitive and thus permits the use of low concentrations of anionophores, comparable to fluorescence-based assays that are used to monitor the influx of $\mathrm{Cl}^{-}$, which facilitates comparisons between anionophores. ${ }^{24}$

An important advantage of this direct and highly sensitive EuL1 assay is that it allows the study of the mechanisms involved in the transmembrane transport of $\mathrm{HCO}_{3}{ }^{-}$. We have revealed that the diffusion of $\mathrm{CO}_{2}$ coupled to protonophoric activity can result in apparent (or net) transport of $\mathrm{HCO}_{3}{ }^{-}$. By this mechanism, the cationophore monensin appears to be able to act as a net transporter of $\mathrm{HCO}_{3}{ }^{-}$, in agreement with previous observation by Gale et $a l^{17}$ and our results with ${ }^{13} \mathrm{C}$ NMR assay (Fig. S19).

Further analysis of transport data by anionophores 1-3 at different concentrations and in combination with monensin, permitted to unravel the mechanisms of the transport observed in the EuL1 assay. We confirmed that bambusuril 1 exclusively acts as $\mathrm{HCO}_{3}{ }^{-} / \mathrm{Cl}^{-}$antiporter, which in combination with the high rates of transport achieved, highlights that this is a promising anionophore for biological applications, provided that it can be delivered to cells.

However, urea $\mathbf{2}$ and thiourea $\mathbf{3}$ combine a mechanism that involves $\mathrm{CO}_{2}$ diffusion and the dissipation of a $\mathrm{pH}$ gradient with $\mathrm{HCO}_{3}{ }^{-} / \mathrm{Cl}^{-}$antiport. These results lead us to consider the possibility that other anionophores which have been reported as $\mathrm{HCO}_{3}{ }^{-}$transporters, and that are able to transport either $\mathrm{H}^{+}$ or $\mathrm{OH}^{-}, 51$ might primarily rely on $\mathrm{CO}_{2}$ diffusion instead of $\mathrm{HCO}_{3}^{-}$transport. Only for very potent anion transporters, for which the rate of total apparent $\mathrm{HCO}_{3}{ }^{-}$transport surpasses the limiting rate of $\mathrm{CO}_{2}$ diffusion, can we conclude with certainty that these act as anionophores for $\mathrm{HCO}_{3}{ }^{-}$.

The EuL1 assay also allowed, for the first time, to study the kinetics of $\mathrm{HCO}_{3}{ }^{-} / \mathrm{NO}_{3}{ }^{-}$exchange. This revealed that thiourea $\mathbf{3}$ and urea $\mathbf{2}$ are efficient transporters for this process, while bambusuril $\mathbf{1}$ performed very poorly, similar to previous observations for $\mathrm{Cl}^{-} / \mathrm{NO}_{3}{ }^{-}$transport by this macrocycle. ${ }^{24}$ Furthermore, it is possible to modulate the anion binding and sensing properties of this class of Eu(III) probes through modifications in the ligand structure, ${ }^{56}$ auguring well for monitoring the transport of other anions using the strategy developed herein.

We are convinced that the new opportunities provided by this assay to study transport of $\mathrm{HCO}_{3}{ }^{-}$ efficiently and in great detail can contribute to the further development of $\mathrm{HCO}_{3}{ }^{-}$transporters for biomedical purposes, such as channel replacement therapies. ${ }^{10,57}$ The assay developed in this work will also inform the future design of $\mathrm{Eu}(\mathrm{III})$ probes capable of monitoring spatio-temporal $\mathrm{HCO}_{3}{ }^{-}$dynamics within living cells. Indeed, a derivative of $\left[E u . L^{1}\right]^{+}$has already been shown to permeate living cells and localise to specific subcellular compartments. ${ }^{58}$ 
The results reported here are part of a project that has received funding from the European Research Council (ERC) under the European Union's Horizon 2020 research and innovation programme (Grant agreement No. 802727). HV is a research associate of the Fonds de la Recherche Scientifique - FNRS. LMC and HV also thank the ULB, "Fonds Van Buuren" and "Fonds Defay" for grants that enabled the purchase of the fluorescence spectrometer. SJB and SHH acknowledge the support of the EPSRC (EP/S032339/1) and the Wellcome Trust (204500/Z/16/Z). VŠ thank the Czech Science Foundation (No. 20-13922S).

\section{References}

${ }^{1}$ M. Tresguerres, J. Buck and L. R. Levin, Pflugers Arch. - Eur. J. Physiol., 2010, 460, 953-964.

${ }^{2}$ E. Cordat and J. R. Casey, Biochem. J., 2009, 417, 423-439.

${ }^{3}$ J. P. Garnett, E. Hickman, R. Burrows, P. Hegyi, L. Tiszlavicz, A. W. Cuthbert, P. Fong and M. A. Gray, J. Biol. Chem., 2011, 286, 41069-41082.

${ }^{4}$ A. Gorbatenko, C. W. Olesen, E. P. Boedtkjer and S. F. P. Pedersen, Front. Physiol., 2014, 5, 130.

${ }^{5}$ J. Y. Choi, D. Muallem, K. Kiselyov, M. G. Lee, P. J. Thomas and S. Muallem, Nature, 2001, 410, 94-97.

${ }^{6}$ M. J. Hug, T. Tamada and R. J. Bridges, News Physiol. Sci., 2003, 18, 38-42.

${ }^{7}$ K. Kunzelmann, R. Schreiber and H. B. Hadorn, J. Cystic Fibrosis, 2017, 16, 653-662.

${ }^{8}$ P. A. Gale, J. T. Davis and R. Quesada, Chem. Soc. Rev., 2017, 46, 2497-2519.

${ }^{9}$ H. Valkenier and A. P. Davis, Acc. Chem. Res., 2013, 46, 2898-2909.

${ }^{10}$ A. P. Davis, D. N. Sheppard and B. D. Smith, Chem. Soc. Rev., 2007, 36, 348-357.

${ }^{11}$ J. T. Davis, P. A. Gale, O. A. Okunola, P. Prados, J. C. Iglesias-Sánchez, T. Torroba and R. Quesada, Nat. Chem., 2009, 1, $138-144$.

${ }^{12}$ S. Hussain, P. R. Brotherhood, L. W. Judd and A. P. Davis, J. Am. Chem. Soc., 2011, 133, 1614-1617.

${ }^{13}$ L. E. Karagiannidis, C. J. E. Haynes, K. J. Holder, I. L. Kirby, S. J. Moore, N. J. Wells and P. A. Gale, Chem. Commun., 2014, 50, 12050-12053.

${ }^{14}$ M. Olivari, R. Montis, S. N. Berry, L. E. Karagiannidis, S. J. Coles, P. N. Horton, L. K. Mapp, P. A. Gale and C. Caltagirone, Dalton Trans., 2016, 45, 11892-11897.

${ }^{15}$ N. Busschaert, P. A. Gale, C. J. E. Haynes, M. E. Light, S. J. Moore, C. C. Tong, J. T. Davis and J. William A. Harrell, Chem. Commun., 2010, 46, 6252-6254.

${ }^{16}$ N. J. Andrews, C. J. E. Haynes, M. E. Light, S. J. Moore, C. C. Tong, J. T. Davis, W. A. Harrell Jr and P. A. Gale, Chem. Sci., 2011, 2, 256-260.

${ }^{17}$ L. A. Jowett, E. N. W. Howe, X. Wu, N. Busschaert and P. A. Gale, Chem. Eur. J., 2018, 24, 10475-10487.

${ }^{18}$ N. Busschaert, I. L. Kirby, S. Young, S. J. Coles, P. N. Horton, M. E. Light and P. A. Gale, Angew. Chem. Int. Ed., 2012, 51, 4426-4430.

${ }^{19}$ I. Marques, P. M. R. Costa, M. Q. Miranda, N. Busschaert, E. N. W. Howe, H. J. Clarke, C. J. E. Haynes, I. L. Kirby, A. M. Rodilla, R. Pérez-Tomás, P. A. Gale and V. Félix, Phys. Chem. Chem. Phys., 2018, 20, 20796-20811.

${ }^{20}$ W. A. Harrell Jr, M. L. Bergmeyer, P. Y. Zavalij and J. T. Davis, Chem. Commun., 2010, 46, 3950-3952.

${ }^{21}$ K. M. Bąk, K. Chabuda, H. Montes, R. Quesada and M. J. Chmielewski, Org. Biomol. Chem., $2018,16,5188-5196$.

${ }^{22}$ P. A. Gale, C. C. Tong, C. J. E. Haynes, O. Adeosun, D. E. Gross, E. Karnas, E. M. Sedenberg, R. Quesada and J. L. Sessler, J. Am. Chem. Soc., 2010, 132, 3240-3241.

${ }^{23}$ E. Hernando, V. Soto-Cerrato, S. Cortés-Arroyo, R. Pérez-Tomás and R. Quesada, Org. Biomol. Chem., 2014, 12, 17711778 .

${ }^{24}$ H. Valkenier, O. Akrawi, P. Jurček, K. Sleziaková, T. Lízal, K. Bartik and V. Šindelář, Chem, 2019, 5, 429-444.

${ }^{25}$ M. Lisbjerg, H. Valkenier, B. M. Jessen, H. Al-Kerdi, A. P. Davis and M. Pittelkow, J. Am. Chem. Soc., 2015, 137, 49484951.

${ }^{26}$ S. Chen, S. Zhang, C. Bao, C. Wang, Q. Lin and L. Zhu, Chem. Commun., 2016, 52, 13132-13135.

${ }^{27}$ B. Shen, X. Li, F. Wang, X. Yao and D. Yang, PLoS ONE, 2012, 7, e34694.

${ }^{28}$ H. Li, H. Valkenier, L. W. Judd, P. R. Brotherhood, S. Hussain, J. A. Cooper, O. Jurček, H. A. Sparkes, D. N. Sheppard and A. P. Davis, Nat. Chem., 2016, 8, 24-32.

${ }^{29}$ E. Hernando, V. Capurro, C. Cossu, M. Fiore, M. García-Valverde, V. Soto-Cerrato, R. Pérez-Tomás, O. Moran, O. ZegarraMoran and R. Quesada, Sci. Rep., 2018, 8, 2608.

${ }^{30}$ M. J. Spooner, H. Li, I. Marques, P. M. R. Costa, X. Wu, E. N. W. Howe, N. Busschaert, S. J. Moore, M. E. Light, D. N. Sheppard, V. Félix and P. A. Gale, Chem. Sci., 2019, 10, 1976-1985.

${ }^{31}$ H. Li, H. Valkenier, A. G. Thorne, C. M. Dias, J. A. Cooper, M. Kieffer, N. Busschaert, P. A. Gale, D. N. Sheppard and A. P. Davis, Chem. Sci., 2019, 10, 9663-9672. 
32 I. Carreira-Barral, M. Mielczarek, D. Alonso-Carrillo, V. Capurro, V. Soto-Cerrato, R. P. Tomás, E. Caci, M. GarcíaValverde and R. Quesada, Chem. Commun., 2020, 56, 3218-3221.

${ }^{33}$ M. Fiore, C. Cossu, V. Capurro, C. Picco, A. Ludovico, M. Mielczarek, I. Carreira-Barral, E. Caci, D. Baroni, R. Quesada and O. Moran, J. Cystic Fibrosis, 2019, 176, 1764-1779.

${ }^{34}$ D. A. Stoltz, D. K. Meyerholz and M. J. Welsh, N. Engl. J. Med., 2015, 372, 351-362.

35 A. Gianotti, V. Capurro, L. Delpiano, M. Mielczarek, M. García-Valverde, I. Carreira-Barral, A. Ludovico, M. Fiore, D. Baroni, O. Moran, R. Quesada and E. Caci, Int. J. Mol. Sci., 2020, 21, 1488.

${ }^{36}$ K. A. Muraglia, R. S. Chorghade, B. R. Kim, X. X. Tang, V. S. Shah, A. S. Grillo, P. N. Daniels, A. G. Cioffi, P. H. Karp, L. Zhu, M. J. Welsh and M. D. Burke, Nature, 2019, 1.

${ }^{37}$ A. V. Koulov, T. N. Lambert, R. Shukla, M. Jain, J. M. Boon, B. D. Smith, H. Li, D. N. Sheppard, J.-B. Joos, J. P. Clare and A. P. Davis, Angew. Chem. Int. Ed., 2003, 42, 4931-4933.

${ }^{38}$ P.-Y. Liu, S.-T. Li, F.-F. Shen, W.-H. Ko, X.-Q. Yao and D. Yang, Chem. Commun., 2016, 52, 7380-7383.

${ }^{39}$ S. J. Butler, Chem. Commun., 2015, 51, 10879-10882.

${ }^{40}$ H. Valkenier, L. W. Judd, H. Li, S. Hussain, D. N. Sheppard and A. P. Davis, J. Am. Chem. Soc., 2014, 136, 12507-12512.

${ }^{41}$ R. Sandeaux, J. Sandeaux, C. Gavach and B. Brun, Biochim. Biophys. Acta, Biomembr., 1982, 684, $127-132$.

${ }^{42}$ K. Nakazato and Y. Hatano, Biochim. Biophys. Acta, Biomembr., 1991, 1064, 103-110.

${ }^{43}$ Y. N. Antonenko, T. I. Rokitskaya and A. Huczyński, Biochim. Biophys. Acta, Biomembr., 2015, 1848, $995-1004$.

${ }^{44}$ D. Łowicki and A. Huczyński, Biomed Res. Int., 2013, 2013, 742149.

${ }^{45}$ C. Ho and J. M. Sturtevant, J. Biol. Chem., 1963, 238, 3499-3501.

${ }^{46}$ A. L. Soli and R. H. Byrne, Mar. Chem., 2002, 78, 65-73.

${ }^{47}$ V. Endeward, M. Arias-Hidalgo, S. Al-Samir and G. Gros, Membranes, 2017, 7, 61.

${ }^{48}$ P. J. F. Henderson, J. D. McGivan and J. B. Chappell, Biochem. J., 1969, 111, 521-535.

${ }^{49}$ S. G. McLaughlin and J. P. Dilger, Physiol. Rev., 1980, 60, 825-863.

50 "Biological Buffers," in CRC Handbook of Chemistry and Physics, 100th Edition (Internet Version 2019), John R. Rumble, ed., CRC Press/Taylor \& Francis, Boca Raton, FL.

${ }_{51}$ X. Wu, L. W. Judd, E. N. W. Howe, A. M. Withecombe, V. Soto-Cerrato, H. Li, N. Busschaert, H. Valkenier, R. PérezTomás, D. N. Sheppard, Y.-B. Jiang, A. P. Davis and P. A. Gale, Chem, 2016, 1, 127-146.

52 T. Sato, H. Konno, Y. Tanaka, T. Kataoka, K. Nagai, H. H. Wasserman and S. Ohkuma, J. Biol. Chem., 1998, 273, 2145521462.

53 J. L. Seganish and J. T. Davis, Chem. Commun., 2005, 5781-5783.

54 Y. Yang, X. Wu, N. Busschaert, H. Furuta and P. A. Gale, Chem. Commun., 2017, 53, 9230-9233.

55 J. P. Clare, A. J. Ayling, J.-B. Joos, A. L. Sisson, G. Magro, M. N. Pérez-Payán, T. N. Lambert, R. Shukla, B. D. Smith and A. P. Davis, J. Am. Chem. Soc., 2005, 127, 10739-10746.

56 S. H. Hewitt, G. Macey, R. Mailhot, M. R. J. Elsegood, F. Duarte, A. M. Kenwright and S. J. Butler, Chem. Sci., 2020, 11, 3619-3628.

${ }_{57}$ R. Quesada and R. Dutzler, J. Cystic Fibrosis, 2020, 19, S37-S41.

58 R. Mailhot, T. Traviss-Pollard, R. Pal and S. J. Butler, Chem. Eur. J., 2018, 24, 10745-10755. 